\title{
ВЕТЕРИНАРНО-САНІТАРНА ОЦНКА ЯКОСТІ І БЕЗПЕЧНОСТІ РИБИ ПІВДЕННОГО РЕГІОНУ УКРАЇНИ (ОГЛЯДОВА СТАТТЯ)
}

\author{
О. Голубенко, О. Коваль, В. Рудь, Л. Тарасенко
}

Одеський державний аграрний університет

В огляді узагальнені дані про захворювання коропу, які зустрічаються у Хаджибейському лимані. У останні роки спостерігається збільшення поширення захворюваності коропових риб $i$ збитки рибництву та іхтіофауні регіону. На основі інформаиіі щзодо розповсюдженості захворювань серед коропу у Південному регіоні Украӥни, був проведений загальний огляд найбільш поширених хвороб коропу. Серед незаразних захворювань найбільщу увагу потрібно приділити аліментарним хворобам, токсикозам, порушенням режиму водойм. Інфекційні хвороби коропа представлені некрозом зябер, краснухою, бронхіомікозом та сапролегніозом. Зустрічаються паразитичні хвороби, які представлені іхтіофтіріозом та аргульозом, та захворювання викликані інфузоріями, триходініоз. У Хаджибейському лимані спостерігається масова загибель риби від перевищення допустимого вмісту сірководню. Для забезпечення високої якості харчовоі сировини і запобігти розповсюдженості захворювань та загибелі риби, потрібно проводити іхтіологічний контроль, ветеринарно-санітарну експертизу та санітарну оцінку якості риби.

Ключові слова: риба, короп, захворювання, гельмінти, водойми, ветеринарно-санітарна оцінка, Хаджибейський лиман.

Постановка проблеми. Велика різноманітність риби у Південному регіоні України обумовлена тим фактором, що тут знаходиться велика кількість природних і штучно створених водойм, наявність яких позитивно впливає на існування риби та ії рівномірного розподілу у водоймах.

У останні декілька років в нашій країні відмічається велика тенденція до розведення риби, переважно коропа, у ставках, кар'єрах, невеликих річках або їх невеликих ділянках, котрі відгороджені сіткою $[1,14]$. Це пов'язано з тим, що короп є найбільш розповсюдженою рибою, економічно прибутковою, не потребує спеціальних умов вирощування та годівлі, дуже швидко росте і розмножується, володіє високими харчовими властивостями та займає важливе місце у харчуванні людей.

Однак, однією з причин, що стає перешкодою риборозведенню і вирощуванню риби у ставках, $є$ захворювання від яких щорічно гине велика кількість риби і це не залежить від того, що короп $\epsilon$ досить стійкою рибою. Проблемним моментом такої ситуації $є$ інфекційні та інвазійні захворювання коропа, котрі впливають на його розвиток та якість продукції, яку отримують у кінцевому результаті $[8,19,21]$.

Тому зараз особливої актуальності набуває ветеринарно-санітарний контроль якості та безпеки харчової продукції рибного походження.

Виходячи 3 цього, наші майбутні дослідження спрямовані на необхідність проведення ветеринарно - санітарної оцінки м'яса коропа та вивчення впливу захворювань інфекційного i інвазійного походження на вихід кінцевої продукції, іiї показники якості та безпечності.

У наш час найголовніше значення має своєчасне проведення іхтіологічного контролю та ветеринарно-санітарної експертизи риби, виявлення локалізації та ліквідацій небезпечних захворювань риб, що несуть загрозу економічному благополуччю водойму і життю та здоров'ю людини.

В багатьох літературних джерелах можна знайти таку інформацію, що епізоотологічне благополуччя водойму у рибному господарстві дає можливість збільшити рибну продуктивність від 8 до $10 \%$ [9].

Науковці стверджують, що у останні роки збільшилась кількість випадків поширення захворювань коропових риб, що призводить до великих економічних збитків у господарствах [8, 9].

Метою даної роботи $\epsilon$ огляд літературних джерел, формулювання висновку щодо розповсюджених захворювань коропа у Хаджибейському лимані. 
Аналіз літературних джерел. Риба та продукція рибного походження займає одне із провідних місць продукції, котру використовують у ланцюзі харчування. М'ясо риби, особливо коропу, забезпечує харчові потреби організму людини, є безцінним джерелом вітамінів, макрота мікроелементів, повноцінних білків, незамінних жирних кислот для повноцінної життєдіяльності.

Вченими доведено, що 3 метою повноцінного забезпечення свого організму вище перерахованими елементами, людина повинна споживати рибу та рибні продукти у кількості 20 кг, але, у останні роки, було встановлено завдяки незалежному опитування населення, що люди споживають не більше 10 кг риби на рік, що на половину нижче необхідної норми споживання [5].

Для належного вживання необхідної норми біологічно-цінних продуктів - риби та рибних продуктів людиною за рік, необхідним є контроль вирощування риби у ставках, відповідність показникам якості і безпечності.

3 цією метою фахівці проводять ветеринарно-санітарну експертизу, іхтіологічний контроль та профілактику захворювань ставкових риб на території України [4].

Захворювання риби негативно впливають на іï біологічні та фізіологічні показники, розвиток, зовнішній стан, також спостерігається масова загибель хворої риби. До основних причин, які займають провідне місце, серед масової загибелі риби, відносять інвазійні та інфекційні хвороби, для лікування яких використовують антибактерійні препарати: нітрофурани, антибіотики, кормові добавки та барвники [16].

Хвороби риб приносять значні економічні збитки аквакультурі України та світу, в цілому. Вивчення закономірностей їх виникнення та поширення, розробка заходів профілактики головна проблема рибництва, оскільки від вирішення цієї проблеми залежить ефективність відтворення та вирощування іхтіофауни та якість і безпечність продукції рибного походження $[11,12]$.

Хаджибейський лиман відноситься до водойм закритого типу зі змінною солоністю, яка знаходиться у межах 6-7\%, так як така солоність не підходить для нересту прісноводної риби, у першу чергу коропа, його запас у лимані поповнюють штучним шляхом. Лиман розташований на північному заході від міста Одеси та відділений від Чорного моря піщаним пересипом. Іхтіофауна лиману не відрізняється біорізноманіттям, видовий склад представлений, приблизно, 30 видами риби які усі мають промислове значення або штучно пересаджені у водойм. Основна риба, яка має важливе значення з промислової точки зору - короп, карась, судак, окунь, бички та товстолобик [17,20].

За багатьма джерелами було встановлено, що запас прісноводної риби у Хаджибейському лимані повністю залежить від зариблення водойма цими видами риби. Доведено, що у останні роки спостерігається значне збільшення солоності цієї водойми, внаслідок втрати зв'язку з морем та зміною кліматичних умов. Збільшення солоності може призвести до такого наслідку, який вплине на рибну промисловість та можливість вирощування риби, насамперед коропу, у зазначеній водоймі $[5,15,18]$.

Багато захворювань Коропових риб, та й загалом риб, не становлять небезпеки для здоров'я та життя людини і тварини, за умови нормальної теплової обробки перед їхнім вживанням. За час своєї еволюції риби чудово пристосувались до середовища свого існування, їхня взаємодія 3 паразитичними організмами має стабільний характер, що супроводжується дуже рідкою загибеллю хазяїна $[3,14]$.

Науковці стверджують, що більш ніж 90\% випадків загибелі та хвороби риби пов'язані 3 недостатньою кількістю кисню у водоймах. Також дуже частим фактором стресу та масової загибелі риби є порушення гідрохімічного режиму, неправильне транспортування риби перепади температури води при iї транспортуванні та переводі в інший водний об'єкт, недотримання санітарних та карантинних вимог, використання в раціоні риби токсичних чи неповноцінних кормів [2, 7].

На незаразні захворювання риб впливає порушення середовище їх існування, до цих захворювань відносять аліментарні захворювання, токсикози, порушення санітарного та гідрохімічного режиму водойм, перепади температури та тиску, травми та інші фактори, 
більшість захворювань виникають внаслідок стресу та зниження імунітету риб, але ці захворювання $\epsilon$ повністю безпечні для людини та тварини.

Але також риби можуть бути резервуарами збудників гельмінтозів, i особливо розповсюдженими є захворювання, викликані гельмінтами - епісторхоз та діфілоботріоз, токсикозів та токсикоінфекцій людини та тварини [7, 13].

Серед інфекційних захворювань риб у південному регіоні, які уражають найчастіше коропа, $\epsilon$ некроз зябер, краснуха, сапролегніоз та бронхіомізм, запалення плавального міхура. Збиток від цих захворювань складається із багатьох чинників, у першу чергу зниження якості рибної продукції [2, 14].

При дослідженні риби, що вирощуються у ставках риболовних господарств та природних водоймах, можна виявити різні паразитичні захворювання. Дуже часто риба, практично, не страждає від їхньої присутності, але при зростанні кількості цих організмів, може спостерігатися захворювання та загибель великої кількості риби. До паразитарних захворювань карпа, що періодично зустрічаються у водоймах Південного регіону України, належать - iхтіофтіріоз, аргульоз, лерніоз, філометроїдоз, ботріоцефальоз, диплостомоз, постодиплостомоз та каріоз [2].

Дуже часто буває, що хвороби Коропоподібних мають не тільки інвазійне походження. Велику шкоду рибному промислу та господарству завдають хвороби, спричинені інфузоріями це найбільш складно влаштовані одноклітинні серед найпростіших . До таких захворювань можна віднести триходініоз, апіомоз, костіоз, сцифідіоз та трихофріоз $[9,15]$.

Від аліментарних, чи незаразних, захворювань завжди страждала рибна промисловість, особливо це стало очевидно, під час переходу з індустріальної аквакультури на високо інтенсивні форми вирощування Коропоподібних.

За своїм походження аліментарні хвороби розподіляються на два види, до першої групи належать захворювання, що пов'язані з використанням у раціоні риби незбалансованих комбікормів по білковому, жировому, вуглеводному, вітамінному та мінеральному складу. Захворювання, що виникають у риб при споживанні недоброякісних кормів, контамінованих бактеріями та грибами, продукти життєдіяльності яких містять окислені жири, відносять до другої групи. Цей вид захворювання зустрічаються у риб всіх вікових груп, але найбільш чутливий до аліментарних захворювань молодняк риб, бо вони впливають на темп та розвиток риби, що може призводити до іï загибелі. Тому правильно підібрані способи та засоби профілактики - висока відповідальність і стратегічне завдання.

Серед розповсюджених захворювань коропа у Хаджибейському лимані що викликані гельмінтами $є$ епісторхоз та діфілоботріоз, серед інфекційних - некроз зябер та краснуха, аліментарні хвороби та масова загибель риби спричинені перевищенням допустимого вмісту сірководню. Зазначені проблеми виникають періодично, в залежності від пори року, та завдають значних збитків іхтіофауні лиману $[2,20]$.

Велику роль відігріє біологічна цінність м'яса коропових. М'ясо коропу за своїми ветеринарно-санітарними показниками має добрі смакові якості, кількість білка у ньому, в середньому, міститься приблизно 15 - $16 \%$, а жиру до $15 \%$. Живий короп є найбільш ціннім продуктом у харчуванні людини та тварини. Він відноситься до риб, котрі найкраще зберігаються у живому вигляді, бо прісноводні риби використовують мало кисню для дихання. Доведено, що риби наділені такою біологічною особливістю, як накопичення у своїх внутрішніх органах великої кількісті жиророзчинних вітамінів A та D, але не тільки жиророзчинні вітаміни входять до складу риби, м'ясо риб багато такими водорозчинними вітамінами, як В1 - тіамін та аневрин, В2 чи рибофлавін, РP чи нікотинова кислота та В12, який має антианемічний фактор.

При житті хімічний склад м'яса коропових риб постійно змінюється у залежності від біологічного стану та умов середовища де була вирощена риба. На хімічні показники впливають такі фактори зовнішнього середовища, як час та місце вилову риби, віку та статті коропу та вмісту жиру і вологи [10].

Короп не відноситься до тих риб, що дуже вимогливі до свого середовища існування. Придатність ставку чи водойму для життєдіяльності коропу повинно відповідати вимогам згідно стандартів вирощування риби та ветеринарно-санітарної оцінки, підходити для біологічних потреб риби та забезпечувати необхідний рівень природної кормової бази коропу. 
Харчова база коропу різноманітна, їх харчування коливається від дрібних рачків, до яких відносять дафнії, циклопи та їх личинки, до личинок комах, черв'яків. Організм коропа дуже добре засвоює штучні корми - комбікорм, макуха.

Висновки. Покращення якості та харчової цінності риби має дуже велике значення для збереження здоров'я тварин та людей, для досягнення цієї мети важливим фактором $\epsilon$ ветеринарно-санітарна оцінка продуктів рибного походження. Особливу увагу слід приділяти продуктам рибного походження, які були отримані від коропу, котрий був уражений різними захворюваннями.

Для того, щоб забезпечити якість та безпечність харчової сировини і м'яса продуктів рибного походження, необхідною умовою є ветеринарно-санітарна експертиза та санітарна оцінка якості риби [19].

Інфекційні та інвазійні захворювання коропу призводять до значних економічних збитків, що негативно впливають на рибне господарство. Тому метою мого подальшого дослідження буде вивчення епізоотичного стану та проведення ветеринарно-санітарної експертизи риби, щодо недопущення появи захворювань, котрі викликають масову загибель коропової риби у Хаджибейському лимані. Подальші дослідження будуть проводитись у цьому напрямку.

Огляд літературних джерел показав, що раніше активних досліджень у цьому напрямку не проводилось, тому вважаємо, що ця робота $\epsilon$ актуальною. В наступних статтях будуть публікуватися окремі фрагменти експериментів та досліджень.

\section{Список використаних джерел}

1. Aral F., Dogu Z. Recent Advances in Fish Farms. InTech, 2011. 262 p.

2. Avice J.C. Ichtyology. In: From Aardvarks to Zooxanthellae, 2017. 55-66 p.

3. Bone Q., Moore R. Biology of Fishes. Taylor\&Francis, 2008. 478 p.

4. Davydov ON, Isaeva NM, Kuruvskaia LY. Ichthyopathological encyclopedia. K: Ukr. fitosocial. centr. 2011. 164 p. (in Russian)

5. Djmil VI. Soroka (2012) Monogenoidozy koropovih rib. Naukovii visnik Nacionalnogo universitety bioresursiv I prirodokoristuvannya Ukraini. Striya: Veretinarna medicina, yakist` I bezpeka produkcii tvarinnictva. Vip. 151, ch.2. 58. 61 p. (in Ukrainian)

6. Genter F., Terwinghe E., Dangyu A. Atlas of Fish Histology. Science Publishers, 2009. 215 p.

7. Giulio R. T., Hinton D.E. The Toxicology of Fishes. CRC Press, 2008. 1101 p.

8. Halat VF, Berezovski AV, Soroka NM, Methodical instructions for the diagnosis of helminthiasis in animals. Kyiv: Vyshcha osvita, 2007. 54 p. (in Ukrainian)

9. Halat VF, Berezovski AV. Parasitology and invasive diseases of animals: Textbook. Kyiv: Urozhai, 2009. 368 p. ( p. 228 - 241) (in Ukrainian)

10. Helfman Gene S. Fish Conservation. London: Island Press, 2007. 600 p.

11. Kottelat M., Freyhof J. Handbook of European freshwater fishes. Delemont, IUCN, 2007. 660

p.

12. Nelson J.S. Fishes of the World. 4thed. Hoboken, New Jersey, 2006. 622 p.

13. Noga E.J. Fish disease. Second edition. Blackwell Publishing, 2012. 519 p.

14. Ponomarev S.V., Bakaneva Iu.M., Fedorovykh Iu.V. Ikhtiologiia. Publ., 2014. 568 p. (in Russian)

15. Prjahin JV, Shkickij VA (2008) Metody rybohozjajstvennyh issledovanij. Rostov-na-Donu: JuNC RAN. 256 p. (in Russian)

16. Roberts R.J. Fish Pathology. $4^{\text {th }}$ ed. Willey-Blackbell. 2012: 590 p.

17. Snigirev, S. M., Finogenov, A. L. (2013). The current state of the industrial fish fauna of the Khadzhibey estuary. 4th international scientific conference: modern problems of theoretical and practical ichthyology: z-b nauk. st., Ternopil' : Vektor, 256-258 p. (in Ukrainian)

18. Tuchovenko Ju.S., Gophenko E.D. (2011) Aktyalnye problem limanov severo-zapadnogo Prichernomor ja: kollektivnja monografija. Odessa: Odesskij gosudarstvenniy ekologicheskiy universitet. 223 p. (in Ukrainian) 
19. Vlizlo VV, Fedoruk RS, Ratych IB. Laboratory Methods of In-vestigation in Biology, Stockbreeding and Veterinary Medicine: a reference book. Lviv, 2012: 764 p. (in Ukrainian)

20. Volja E.G., Druhin A.I., Chernikov G.B. (2006). Haracteristika sovremennogo sostojanaja ihtiofauny Hadzhibejskogo limana. Akademiku L.S. Bergu. 130 let: Sbornik nauchnyh statej, p. 62. 65. (in Ukrainian)

21. Zazharska VM., Kuzak RS, Biben IA, Kuneva LV. Veterinary and sanitary examination. Dnipro, 2017. 193 p. (in Ukrainian)

\section{ВЕТЕРИНАРНО-САНИТАРНАЯ ОЦЕНКА КАЧЕСТВА И БЕЗОПАСНОСТИ РЫБЫ ЮЖНОГО РЕГИОНА УКРАИНЫ (ОБЗОРНАЯ СТАТЬЯ)}

Голубенко Е, Коваль О., Рудь В., Тарасенко Л.

В обзоре обобщены данные про болезни карпа, которые встречаются в Хаджибеевском лимане. В последние года наблюдается увеличение распространения болезненности карповых рыб и убытки рыболовству и ихтиофауне региона. На основании информачии по распространению заболеваний среди карпа в Южном регионе Украины, был проведен общий осмотр более распространенных болезней карпа. Среди незаразных болезней большее внимание нужно отвести алиментарным болезням, токсикозам, нарушению режима водоёмов. Инфекционные болезни карпа представлены некрозом жабр, краснухой, бранхиомикозом $u$ сапролегниозом. Встречаются паразитарные болезни, которые представлены ихтиофтириозом и аргулёзом, и заболеваниями вызванными инфузориями. В Хаджибеевском лимане наблюдается массовая гибель рыбы от превышения допустимого содержания сероводорода. Для обеспечения высокого качества продуктового сырья и предотвратить распространение заболевания и гибель рыбы, необходимо проводить ихтиологический контроль, ветеринарно-санитарную экспертизу та санитарную оценку качества рыбы.

Ключевые слова: рыбы, карп, заболевания, гельминты, водоёмы, ветеринарно-санитарная оценка, Хаджибеевский лиман.

\section{VETERINARY SND SANITARY ASSESSMENT OF FISH QUALITY AND SAFETY IN THE SOUTHERN REGION OF UKRAINE (REWIEW ARTICLE)}

Holubenko O., Koval O., Rud V., Tarasenko L.

In a review summarized data about a disease to the carp, that meet in Khadzhibey estuary. In recent year there are an increase of distribution of morbidity of carp fishes and losses to the fish-farming and fish fauna of region. On the base of information on prevalence of diseases among to the carp in the South region of Ukraine, a general review most spread disease to the carp was conducted. Among noncontagious diseases most attention needs to be spared to alimentary illnesses, toxicosis, by violation of the mode of reservoirs. The infectious diseases of carp are presented by necrosis of branchiaes, german measles, branchiomycosts and saprolegnia infection. There are parasitic illnesses that is presented parasitic ciliate (ichthyophthirius multifiliis), fish louse (argulus foliaceus) and diseases are caused by infusoria (trichodina). In Khadzhibey estuary there is mass death of fish from exceeding of possible maintenance to the sulphuretted hydrogen. For providing of high quality of food raw material and to prevent prevalence of diseases and death do, it is needed to conduct ichthyological control, veterinary and sanitary examination and sanitary estimation of quality of fish.

Key words: fish, carp, disease, helmints, reservoirs, veterinary and sanitary estimation, Khadzhibey estuary. 